\title{
PENGEMBANGAN MEDIA PEMBELAJARAN INTERAKTIF BERBASIS TIK PADA MATA PELAJARAN BIOLOGI
}

\author{
Zahara Mursida \\ Guru MAN Idi Rayeuk Aceh Timur \\ zahara.mrsd@gmail.com
}

\begin{abstract}
Abstrak: Tujuan dari penelitian ini adalah untuk: (1) menghasilkan produk bahan ajar media pembelajaran interaktif berbasis TIK dalam bentuk CD untuk pembelajaran biologi yang digunakan sebagai media pembelajaran, (2) Mengetahui efektifitas produk bahan ajar media pembelajaran interaktif berbasis TIK dalam bentuk CD yang dikembangkan untuk pembelajaran TIK lebih efektif dibandingkan dengan menggunakan buku teks. Simpulan dari penelitian yaitu (1) hasil validasi dari ahli materi terhadap media pembelajaran interaktif yang telah dikembangkan menunjukkan kategori "sangat baik", (2) Hasil validasi dari ahli desain pembelajaran terhadap media pembelajaran interaktif pada pembelajaran yang dikembangkan menunjukkan kategori "sangat baik", (3) hasil validasi dari ahli rekayasa perangkat lunak terhadap media pembelajaran interaktif yang dikembangkan dinyatakan pada kategori "sangat baik", (4) Terhadap penggunaan media pembelajaran interaktif pada tes hasil belajar menunjukkan bahwa hasil belajar siswa yang dibelajarkan dengan menggunakan media pembelajaran interaktif (kelas eksperimen) lebih tinggi dari pada hasil belajar siswa yang dibelajarkan dengan menggunakan buku teks (kelas kontrol), (5) Media pembelajaran interaktif memiliki keefektifan lebih tinggi dari keefektifan menggunakan buku teks.
\end{abstract}

Kata Kunci: pengembangan, media pembelajaran interaktif, berbasis TIK, biologi.

Abstract: The purpose of this research is to: (1) produce instructional products of ICT-based interactive learning media in the form of CDs for biology learning used as instructional media, (2) to know the effectiveness of instructional products of ICT-based interactive learning media in the form of CDs developed for ICT learning is more effective than using textbooks. The conclusion of the research is (1) the validation result from the material expert to the interactive learning media that has been developed shows the category "very good", (2) The validation result from the instructional design expert to the interactive learning media on the developed learning shows the category "very good" (3) validation results from software engineering experts on interactive learning media developed are stated in the category of "very good", (4) Against the use of interactive learning media on the test of learning results show that the learning outcomes of students who are taught by using interactive learning media (class experiment) is higher than the learning outcomes of students who are taught by using textbooks (control class), (5) Interactive learning media have a higher effectiveness of the effectiveness of using textbooks.

Keywords: development, interactive learning media, ICT-based, biology.

\section{PENDAHULUAN}

Standar kompetensi dalam kurikulum pembelajaran biologi menyediakan berbagai pengalaman belajar untuk memahami konsep dan proses sains. Keterampilan proses ini meliputi keterampilan mengamati, mengajukan hipotesis, menggunakan alat dan bahan secara baik dan benar dengan selalu mempertimbangkan keamanan dan keselamatan kerja, mengajukan pertanyaan, menggolongkan dan menafsirkan data, serta mengkomunikasikan hasil temuan secara lisan atau tertulis, menggali dan memilah informasi faktual yang relevan untuk menguji gagasangagasan atau memecahkan masalah sehari-hari.

Biologi merupakan salah satu bagian ilmu pengetahuan alam yang menekankan pemberian pengetahuan langsung kepada siswa secara alamiah. Tetapi, hasil pembelajaran biologi di sekolah masih kurang memuaskan, apalagi bila dikaitkan dengan pemahaman siswa terhadap materi pelajaran. Walaupun banyak siswa yang mampu menghapal materi, tetapi kenyataannya siswa seringkali tidak memahami 
secara mendalam pengetahuan yang bersifat hapalan itu. Bahkan siswa tidak mampu menghubungkan apa yang dipelajari dengan manfaat pengetahuan itu sendiri.

Berdasarkan observasi dan data laporan guru dan siswa bahwa dalam pembelajaran di MAN Model Idi Rayeuk Aceh Timur masih kurang. Nilai siswa yang diperoleh sejak tiga tahun yang lalu sangat sedikit, disebabkan karena minat belajar siswa berkurang.

Dalam hal ini untuk meningkatkan hasil belajar siswa, guru dituntut untuk menjadikan pembelajaran lebih inovatif, yang dapat mendorong siswa untuk belajar secara optimal, baik belajar secara mandiri maupun belajar di dalam kelas. Pengembangan bahan ajar adalah salah satu solusi yang harus dilakukan oleh guru dan diharapkan dapat membantu memecahkan permasalahan dalam pembelajaran. Disamping pengembangan bahan ajar, guru juga diharapkan mampu memanfaatkan dan mengembangkan media pembelajaran.

Oleh karena itu, siswa dan guru sangat membutuhkan media yang bisa mengatasi masalah-masalah yang sedang dialaminya saat ini. Media yang dibutuhkan adalah media pembelajaran interaktif yang dapat membantu sistem pembelajaran yang ada pada sekolah MAN Model Idi Rayeuk Aceh Timur ini.

Menurut Hamalik (2005:

"Pengertian belajar merupakan suatu proses, suatu kegiatan dan bukan suatu hasil atau tujuan". Belajar bukan hanya mengingat, akan tetapi lebih luas dari itu, yakni mengalami. Hasil belajar bukan suatu penguasaan hasil latihan melainkan pengubahan kelakukan. Pengertian ini sangat berbeda dengan pengertian lama tentang belajar, yang menyatakan bahwa belajar adalah memperoleh pengetahuan, belajar adalah latihan-latihan pembentukan kebiasaan secara otomatis dan seterusnya. Sejalan dengan perumusan di atas, ada pula tafsiran lain tentang belajar yang menyatakan, bahwa belajar adalah suatu perubahan tingkah laku individu melalui interaksi dengan lingkungan. Dibandingkan dengan pengertian pertama maka jelas tujuan belajar itu prinsipnya sama, yakni perubahan tingkah laku, hanya berbeda cara atau usaha pencapainnya. Pengertian ini menitik beratkan pada interaksi antara individu dengan lingkungan. Di dalam interaksi inilah terjadi serangkaian pengalaman - pengalaman belajar.
Sabari (2007:19) belajar adalah proses perubahan perilaku berkat pengalaman dan pelatihan. Artinya tujuan kegiatan belajar ialah perubahan tingkah laku, baik yang menyangkut pengetahuan, ketrampilan, sikap bahkan meliputi segenap aspek pribadi. Kegiatan pembelajaran seperti mengorganisasi pengalaman belajar, menilai proses dan hasil belajar, termasuk dalam cakupan tanggung jawab guru.

Sabari (2007:106) media secara harfiah memiliki arti "perantara" atau pengantar. Menurut Association For education and Communication Technologi (AECT), media adalah segala bentuk yang diprogramkan untuk suatu proses penyaluran infomasi. Sedangkan menurut Education Association, media merupakan benda yang dimanipulasikan, dilihat, didengar, dibaca atau dibicarakan beserta instrumen yang dipergunakan dengan pembelajaran, dapat mempengaruhi efektifitas program instruksional. Media merupakan alat yang digunakan sebagai perantara untuk menyampaikan pesan dan dapat meransang pikiran, perasaan dan kemajuan audiens (siswa) sehingga dapat mendorong terjadinya proses pembelajaran. Media pembelajaran merupakan suatu sarana atau alat bantu guru untuk menyampaikan pesan ataupun informasi agar dapat diterima dengan baik dan menarik oleh siswa. Pemilihan media pembelajaran yang tepat akan berpengaruh dalam mewujudkan tercapainya pembelajaran yang lebih optimal. Media dalam pembelajaran memiliki fungsi sebagai alat bantu untuk memperjelas pesan yang disampaikan oleh guru. Media juga berfungsi untuk pembelajaran individual dimana kedudukan media sepenuhnya melayani kebutuhan belajar siswa. Guru yang efektif dalam menggunakan media dapat meningkatkan minat siswa dalam proses pembelajaran dan siswa akan lebih cepat dan mudah memahami dan mengerti terhadap materi pelajaran yang disampaikan guru.

Pembelajaran adalah proses interaksi peserta didik dengan pendidik dan sumber belajar pada suatu lingkungan belajar. Pembelajaran merupakan usaha sengaja, terarah dan bertujuan agar orang lain dapat memperoleh pengalaman yang bermakna. Pembelajaran biologi di sekolah menengah diharapkan dapat menjadi wahana bagi peserta didik untuk mempelajari diri sendiri dan alam sekitar serta proses pengembangan lebih lanjut dalam penerapannya di kehidupan sehari-hari. 
Penting sekali bagi setiap guru memahami sebaik-baiknya tentang proses belajar siswa, agar dapat memberikan bimbingan dan menyediakan lingkungan belajar yang tepat dan serasi bagi siswa (Oemar Hamalik, 2010:36).

Yamin (2013:15) pembelajaran merupakan salah satu sub sistem dari sistem pendidikan, di samping kurikulum, konseling, administrasi, dan evaluasi. Wikipedia mengemukakan pembelajaran (instruction) sebagai suatu bentuk informasi yang dikomunikasikan dapat berupa komando atau penjelasan dengan bagaimana cara bertindak, perilaku, cara memulai tugas, cara melengkapi, atau cara melaksanakan sesuatu (http:/en.wikipedia.org/wiki/Instruction).
Menurut
Miarso
(2004:545), pembelajaran aalah suatu usaha yang disengaja, bertujuan, dan terkendali agar orang lain belajar atau terjadi perubahan yang relatif menetap pada diri orang lain. Usaha tersebut dapat dilakukan oleh seseorang atau sekelompok orang yang memiliki kemampuan atau kompetensi dalam merancang dan atau mengembangkan sumber belajar yang diperlukan. Dapat pula dikatakan bahwa pembelajaran adalah usaha yang dilakukan oleh pendidik atau orang dewasa lainnya untuk membuat pebelajar dapat belajar dan mencapai hasil belajar yang maksimal.

Sebagai salah satu jenis media dalam pembelajaran, multimedia pembelajaran terbagi menjadi dua yaitu definisi sebelum tahun 1980an dan definisi sesudah tahun1980-an. Sebehun tahun 1980-an atau pada era 1960-an, menurut Barker dan Tucker (dalam Sunaryo Soenarto 2005), multimedia diartikan sebagai kumpulan dari berbagai peralatan rnedia berbeda yang digunakan untuk presentasi. Dalam pengertian ini multimedia diartikan sebagai ragam media yang digunakan untuk penyajian materi pelajaran, misalnya penggunaan wall chart atau grafik yang dibuat di atas kertas karton yang ditempelkan di dinding. Tan Seng Chee \& Angela F.L.Wong (2003) menyatakan bahwa multimedia secara tradisional merujuk kepada penggunaan beberapa media sedangkan multimedia pada zaman sekarang merujuk kepada penggunaan gabungan beberapa media dalam penyajian pembelajaran melalui komputer.

Karakteristik terpenting pada media pembelajaran interaktif adalah bahwa siswa tidak hanya memperhatikan penyajian atau objek, tetapi dipaksa untukberinteraksi selama mengikuti pelajaran. Menurut Miarso (2004:465) paling sedikit ada tiga macam interaksi yang dapat diidentifikasi. Pada tingkat pertama siswa dengan sebuah program, misalnya mengisi blanko pada teks yang terprogram. Tingkat berikutnya siswa berinteraksi dengan mesin, misalnya mesin pembelajaran, simulator, laboratorium bahasa atau terminal komputer. Bentuk ketiga media interaktif adalah yang mengatur interaksi antar siswa secara teratur tetapi tidak ter-program.

Media pembelajaran Interaktif adalah suatu cara atau teknik pembelajaran yang digunakan guru pada saat menyajikan bahan pelajaran dimana guru pemeran utama dalam menciptakan situasi interaktif yang edukatif, yakni interaksi antara guru dengan siswa, siswa dengan siswa dan dengan sumber/media pembelajaran dalam menunjang tercapainya tujuan belajar. Menurut Syah (1998) proses belajar mengajar keterlibatan siswa harus secara totalitas, artinya melibatkan pikiran, penglihatan, pendengaran dan psikomotor. Dalam proses mengajar seorang guru harus mengajak siswa untuk mendengarkan, menyajikan media yang dapat dilihat, memberi kesmpatan untuk menulis dan mengajukan pertanyaan atau tanggapan sehingga terjadi dialog kreatif yang menunjukan proses belajar mengajar yang interaktif.

Miarso (2005:536) mengatakan bahwa pembelajaran yang efektif antara lain; (a) pengorganisasian pembelajaran dengan baik; (b) komunikasi secara efektif; (c) penguasaan dan antusiasme pada mata diklat; (d) sikap positif terhadap siswa ; (e) pemberian nilai ujian yang adil; (f) keluwesan dalam pendekatan pengajaran ; dan (g) hasil belajar siswa yang baik. Miarso (2005:536) mengatakan bahwa pembelajaran yang efektif adalah yang menghasilkan belajar yang bermanfaat dan bertujuan bagi mahasiswa, melaui prosedur yang tepat.

Strategi pembelajaran adalah spesifikasi untuk seleksi dan mengatur kejadian-kejadian dan kegiatan-kegiatan dalam satuan pelajaran (seels \& Richey, 1994:31). Menurut Reigeluth (1999:400) bahwa strategi pembelajaran sebagai metode-metode untuk memanipulasi untuk unsur-unsur bahan-bahan pengetahuan.

Dalam penelitian ini peneliti akan menggunakan model Dick \& Carey. Dick \& Carey memulaikan modelnya dengan identifikasi tujuan yang dilanjutkan pada 
analisis tujuan dengan memperhitungkan pengetahuan pra-syarat dan pengetahuan bawahan, langkah ini juga mempertimbangkan karakteristik peserta didik sebagai pemakai atau subjek belajar, kemudian perancang diminta menulis tujuan merupakan sasaran yang hendak dicapai. Seterusnya instrumen penilaian harus mengacu pada tujuan pembelajaran yang telah ditulis, guru tidak dibenarkan menilai peserta didik tanpa mengacu pada tujuan yang telah ditulisnya. Langkah berikutnya adalah mengembangkan strategi yang baik, tepat sasaran sesuai muatan materi yang hendak dipelajari oleh peserta didik . Pengembangan materi pembelajaran setelah strategi dirancang dengan sempurna maka dilakukan evaluasi formatif, guru melihat kekuatan rancangan yang telah dibuat, sisi mana terjadi kelemahan dan kekurangan yang harus diperbaiki. Jika semuanya sudah baik, maka guru dapat melaksanakan penilaian sumatif.

Rumusan masalah dalam penelitian ini adalah sebagai berikut: (1) Apakah produk bahan ajar media pembelajaran interaktif berbasis TIK dalam bentuk CD yang dikembangkan untuk pembelajaran biologi layak untuk digunakan sebagai media pembelajaran?, (2) Apakah Produk bahan ajar media pembelajaran interaktif berbasis TIK dalam bentuk CD yang dikembangkan untuk pembelajaran biologi lebih efektif dibandingkan dengan menggunakan buku teks?.

\section{METODE}

Penelitian ini dilaksanakan di MAN Idi Rayeuk Aceh Timur yang berlokasi jalan Medan - Banda Aceh pada siswa kelas X semester genap. Populasi dalam penelitian ini adalah seluruh siswa kelas X MAN Idi Rayeuk Aceh Timur yang berjumlah 8 kelas dengan jumlah keseluruhan 320 siswa.

Pengambilan sampel dilakukan dengan random sampling. Tahap pelaksanaan penelitian ini dilaksanakan pada akhir semester ganjil dengan sampel yang terdiri dari satu kelas berjumlah 40 orang peserta didik.

Model pengembangan diartikan sebagai proses desain konseptual dalam upaya peningkatan fungsi dari model yang telah ada sebelumnya, melalui penambahan komponen pembelajaran yang dianggap dapat meningkatkan kualitas pencapaian tujuan (Sugiarta, 2007:11). Pengembangan model dapat diartikan sebagai upaya memperluas untuk membawa suatu keadaan atau situasi secara berjenjang kepada situasi yang lebih sempurna atau lebih lengkap maupun keadaan yang lebih baik.

Pengembangan disini artinya diarahkan pada suatu program yang telah atau sedang dilaksanakan menjadi program yang lebih baik. Hal ini seiring dengan pendapat yang dikemukakan oleh Adimiharja dan Hikmat (2001:12) dalam Sugiarta (2007:24) bahwa "pengembangan meliputi kegiatan mengaktifkan sumber, memperluas kesempatan, mengakui keberhasilan, dan mengintergrasikan kemajuan".

Model Dick \& Carey (2005) digolongkan sebagai model yang berorientasi pada dua hal yaitu : (1) Pengetahuan, apabila model tersebut dipakai sebagai sumber informasi tentang konsep-konsep, prinsipprinsip perancangan instruksional dan langkahlangkahnya, dan (2) Hasil, dengan menerapkan konsep-konsep dan prinsip-prinsip perancangan yang menghasilkan suatu bahan instruksional yang dapat dipakai belajar secara mandiri tanpa bantuan guru. Disini pun evaluasi dilaksanakan berulang kali sampai dapat diperoleh hasil yang memuaskan.

Analisis data dalam penelitian ini menggunakan analisis deskriptif kuantitatif. Semua data yang terkumpul dianalisis dengan teknik statistik deskriptif yang secara kuantitatif dipisahkan menurut kategori untuk mempertajam penilaian dalam menarik kesimpulan.

Teknik pengumpulan data pada penelitian pengembangan ini adalah angket yang disebar ke beberapa validator. Instrumen pengumpulan data pada pengembangan ini berupa instrumen penilaian untuk menilai produk yang telah dikembangkan. adalah :

Hipotesis penelitian yang akan diuji

$$
\begin{aligned}
& \mathrm{H}_{0}:{ }_{1=}^{\mu}{ }_{2} \\
& \mathrm{Ha}:{ }^{\mu}>{ }_{1}{ }_{2}
\end{aligned}
$$

Keterangan :

$\mu_{1} \quad=$ Rata-rata hasil belajar siswa yang diajar menggunakan media pembelajaran Interaktif dalam bentuk $\mathrm{CD}$.

$\mu_{2} \quad$ = Rata-rata hasil belajar siswa yang diajar dengan menggunakan Buku teks.

$\mathrm{H}_{\mathrm{o}} \quad$ = Tidak ada perbedaan hasil belajar siswa yang diajar dengan menggunakan buku teks 
lebih tinggi dari siswa yang diajar dengan menggunakan media pembelajaran Interaktif .

$\mathrm{H}_{\mathrm{a}}=$ Ada perbedaan hasil belajar siswa yang diajar dengan menggunakan Buku teks lebih tinggi dari siswa yang diajar dengan tidak menggunakan media pembelajaran Interaktif .

\section{HASIL PENELITIAN}

Hasil penilaian oleh ahli materi, ahli desain pembelajaran dan ahli rekayasa perangkat lunak pada setiap aspek penilaian secara keseluruhan ditentukan oleh skor ratarata pada kategorinya masing-masing. Hasil penilaian tersebut kemudian dianalisis untuk menentukan layak tidaknya, dikembangkan media pembelajaran interaktif pada pembelajaran Biologi. Adapun persentase ratarata dari hasil penilaian ahli materi, ahli desain pembelajaran dan ahli rekayasa perangkat lunak akan diuraikan sebagai berikut:

\section{Analisis Data Hasil Evaluasi Ahli Materi}

Tabel 1. Persentase Rata-Rata Hasil Penilaian Terhadap Media Pembelajaran Interaktif Pada Pembelajaran Materi Oleh Ahli Materi

\begin{tabular}{|c|c|c|c|}
\hline No & Kategorisasi & $\begin{array}{c}\text { Persentase Rata- } \\
\text { rata }\end{array}$ & Kriteria \\
\hline 1 & Kualitas materi pembelajaran & $93,73 \%$ & Sangat Baik \\
\hline 2 & Kualitas strategi pembelajaran & $88,00 \%$ & Sangat Baik \\
\hline 3 & Sistem penyampaian pembelajaran & $90,00 \%$ & Sangat Baik \\
\hline \multicolumn{2}{|r|}{ Rata-rata } & $\mathbf{9 0 , 5 7 \%}$ & Sangat Baik \\
\hline
\end{tabular}

Ahli materi menilai media pembelajaran interaktif mata pelajaran Biologi berdasarkan tiga kategori yaitu kualitas materi pembelajaran, kualitas strategi pembelajaran dan sistem penyampaian pembelajaran yang menunjukkan persentase rata-rata penilaian 90,57\% .Pada aspek kualitas materi pembelajaran, 93,73\%, pada kualitas strategi pembelajaran 88,00 \%, dan pada aspek sistem penyampaian pembelajaran 90,00 \% termasuk kategori sangat baik secara keseluruhan, yang berarti media pembelajaran interaktif pada pembelajaran Biologi dapat memenuhi tuntutan kebutuhan pembelajaran.

\section{Analisis Data Hasil Evaluasi Ahli Desain Pembelajaran}

Tabel 2. Persentase Rata-Rata Hasil Penilaian Terhadap Media Pembelajaran Interaktif pada Pembelajaran Biologi Oleh Ahli Desain Pembelajaran

\begin{tabular}{|l|l|l|l|}
\hline No & Kategorisasi & $\begin{array}{l}\text { Persentase Rata- } \\
\text { rata }\end{array}$ & Kriteria \\
\hline 1 & Aspek kelayakan isi & $86,66 \%$ & Sangat Baik \\
\hline 2 & Aspek penyajian & $85,00 \%$ & Sangat Baik \\
\hline 3 & Aspek kebahasaan & $83,00 \%$ & Sangat Baik \\
\hline 4 & Aspek Kegrafikan & $70,00 \%$ & Baik \\
\hline Rata-rata & $\mathbf{8 1 , 1 6 \%}$ & Sangat Baik \\
\hline
\end{tabular}

Penilaian ahli desain pembelajaran terhadap aspek Kelayakan isi desain pembelajaran menunjukkan persentase rata-rata $86,66 \%$ termasuk kategori "Sangat Baik" yang berarti dalam meyampaikan materi pelajaran materi yang disajikan didesain semenarik mungkin sehingga memotivasi siswa untuk belajar. Aspek penyajian menunjukkan persentase rata-rata $85,00 \%$ termasuk kategori "Sangat Baik" berari dalam penyajian pembelajaran sudah dapat tercipta suatu kondisi yang mampu memotivasi minat belajar siswa. Aspek kebahasaan 83,00 \% termasuk kategori "Sangat Baik" berarti penulisan bahasa yang digunakan sudah bagus. Aspek kegrafikan menunjukkan persentase rata-rata $70,00 \%$ termasuk kategori "Baik" hal ini berarti media interaktif yang dikembangkan memiliki tampilan yang menarik sehingga mampu menimbulkan rasa ketertarikan siswa untuk melakukan pembelajaran.

\section{Analisis Data Hasil Evaluasi Ahli Rekayasa Perangkat Lunak}


Tabel 3. Persentase Rata-Rata Hasil Penilaian Terhadap Media Pembelajaran Interaktif Pada Pembelajaran Biologi Oleh Ahli Rekayasa Perangkat Lunak.

\begin{tabular}{|c|l|c|c|}
\hline No & Kategorisasi & $\begin{array}{r}\text { Persentase Rata- } \\
\text { rata }\end{array}$ & Kriteria \\
\hline 1 & Aspek Pemprograman & $86,25 \%$ & Sangat Baik \\
\hline 2 & Aspek Kualitas teknis/tampilan & $85,71 \%$ & Sangat Baik \\
\hline \multicolumn{2}{r|}{ Rata-rata } & $\mathbf{8 5 , 9 8 \%}$ & Sangat Baik \\
\hline
\end{tabular}

Penilaian ahli desain rekayasa perangkat lunak terhadap aspek pemprograman menunjukkan persentase rata-rata $86,25 \%$ termasuk kategori "Sangat baik" yang berarti program perangkat lunak pada media pembelajaran interaktif pada pembelajaran Biologi berfungsi dengan baik bagi siswa dalam memberi kemudahan dalam mendapatkan informasi yang diinginkan. Penilaian ahli desain rekayasa perangkat lunak pembelajaran terhadap aspek kualitas teknis/tampilan menunjukkan skor rata-rata $85,71 \%$ termasuk kategori "Sangat Baik", yang berarti media pembelajaran interaktif pada pembelajaran Biologi dapat memberikan motivasi dan mampu menciptakan kondisi yang mampu memfasilitasi proses pembelajaran bagi siswa.
Berdasarkan penelitian yang telah dilakukan terhadap hasil belajar Biologi pada siswa yang dibelajarkan dengan media pembelajaran interaktif, ditemukan bahwa skor hasil belajar siswa dari 40 siswa tersebar pada rentang $18-29$. Dari hasil perhitungan menunjukkan bahwa skor terendah 18 dan skor tertinggi 29 , mean 24,7 modus 30,5 median 31,6 , varians 7,56 dan simpangan baku 2,749. Untuk melihat skor siswa digunakan kelas interval yaitu skor antara, frekuensi absolut yaitu jumlah siswa yang memiliki skor hasil belajar, dan frekuensi relatif yaitu jumlah persen skor hasil belajar. Secara lengkap gambaran tentang hasil belajar Biologi dengan menggunakan media pembelajaran interaktif ditunjukkan pada Tabel 4.

Tabel 4. Deskripsi Data Hasil Belajar Biologi yang Dibelajarkan Dengan Menggunakan Media Pembelajaran Interaktif

\begin{tabular}{|c|c|c|c|}
\hline No & Interval Kelas & $\begin{array}{c}\text { F } \\
\text { Absolut }\end{array}$ & F Relatif \\
\hline 1 & $18-19$ & 2 & $5 \%$ \\
\hline 2 & $20-21$ & 3 & $7,5 \%$ \\
\hline 3 & $22-23$ & 7 & $17,5 \%$ \\
\hline 4 & $24-25$ & 13 & $32,5 \%$ \\
\hline 5 & $26-27$ & 7 & $17,5 \%$ \\
\hline 6 & $28-29$ & 8 & $20 \%$ \\
\hline \multicolumn{2}{|r|}{ Jumlah } & 40 & $100 \%$ \\
\hline
\end{tabular}

Tabel 4. menunjukkan data hasil belajar Biologi siswa yang dibelajarkan dengan menggunakan media pembelajaran interaktif, diperoleh 2 orang (5\%) berada di bawah kelas ratarata, 3 orang $(7,5 \%)$ berada di bawah rata-rata, sedangkan 7 orang $(17,5 \%)$ berada di bawah ratarata dan 13 orang $(32,5 \%)$ berada di atas rata-rata. Selanjutnya data disusun dalam bentuk diagram histogram seperti terlihat pada gambar 1 berikut ini. 


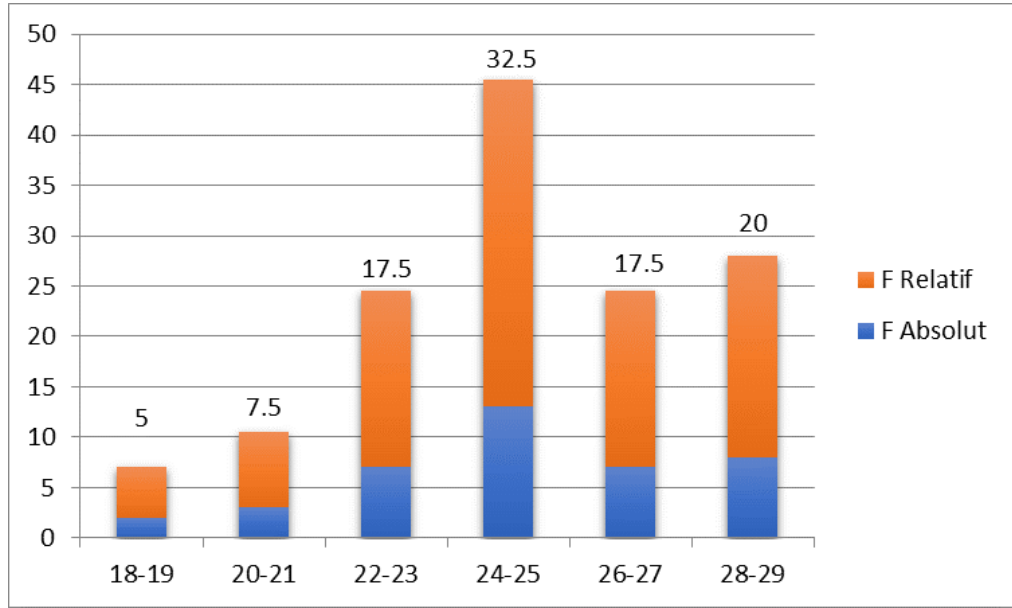

Gambar 1. Histogram Hasil Belajar Biologi Siswa yang Dibelajarkan Dengan Media Pembelajaran Interaktif

\section{Uji Normalitas Data}

Uji normalitas dilakukan untuk mengetahui apakah sebaran skor variabel yang diteliti berasal dari populasi yang berdistribusi normal. Untuk mengetahui hal ini dilakukan dengan menggunakan uji Lilliefors

Berdasarkan hasil perhitungan uji normalitas untuk variabel penggunaan media pembelajaran interaktif diperoleh hitung sebesar 0,0853 harga tabel pada Lilliefors sebesar 0,14019 Untuk varibel penggunaan buku teks diperoleh harga hitung sebesar 0,1341 sedangkan harga tabel pada Lilliefors sebesar 0,14019 Maka dapat disimpulkan bahwa sampel berasal dari populasi yang berdistribusi normal.

\section{Uji Homogenitas Data}

Untuk menguji homogenitas variansi data dilakukan dengan rumus $F$. Hasil pengujian menunjukkan bahwa varians pada kelas eksperimen (penggunaan media pembelajaran interaktif) $=7,56$ dan varians pada kelas kontrol (penggunaan buku teks) $=$ 6,99. Dengan membagikan varians terbesar dengan varians terkecil maka diperoleh $\mathrm{F}_{\text {hitung }}$ sebesar 1,081. Sedangkan $F_{\text {tabel }}$ 1,69. Karena $F_{\text {hitung }}$ lebih kecil dari $F_{\text {tabel }}$ maka dapat disimpulkan bahwa data pada penelitian ini adalah homogen.

Hipotesis yang diajukan pada penelitian ini adalah terdapat perbedaan yang signifikan antara hasil belajar siswa yang dibelajarkan dengan penggunaan media pembelajaran interaktif dan hasil belajar siswa yang dibelajarkan dengan penggunaan buku teks. Rumus yang digunakan untuk uji hipotesis adalah uji-t. Dari hasil pengolahan data diperoleh $t_{\text {hitung }}$ sebesar 1,8573 sedangkan $t_{\text {tabel }}$ pada $\alpha=5 \%$ adalah 1,69 . Karena thitung $(1,857)$ lebih besar dari $t_{\text {tabel }}(1,69)$ maka disimpulkan bahwa ada perbedaan yang signifikan antara hasil belajar siswa yang dibelajarkan dengan penggunaan media pembelajaran interaktif dan hasil belajar siswa yang dibelajarkan dengan penggunaan buku teks.

Nilai keefektifan media pembelajaran intreaktif sebesar $82,25 \%$ yang diuraikan sebagai berikut:

$$
\begin{aligned}
X & =\frac{\text { jumlah skor yang diperoleh }}{\text { jumlah skor ideal }} \times 100 \% \\
X & =\frac{987}{1200} \times 100 \% \\
& =82,25 \%
\end{aligned}
$$

Nilai keefektifan penggunaan buku teks sebesar 78,5\% yang diuraikan sebagai berikut: jumlah skor yang diperoleh

$$
\begin{aligned}
X & =\frac{942}{\text { jumlah skor ideal }} \times 100 \% \\
X & =1200 \times 100 \% \\
& =78,5 \%
\end{aligned}
$$

Hal ini berarti hasil belajar siswa yang dibelajarkan dengan dengan penggunaan media pembelajaran interaktif $(82,25 \%)$ lebih tinggi dari hasil belajar siswa yang dibelajarkan dengan peggunaan buku teks $(78,5 \%)$.

\section{PEMBAHASAN}

Produk pengembangan media pembelajaran interaktif pada Pembelajaran Biologi merupakan materi pembelajaran Biologi yang telah dikembangkan dengan memperhatikan aspek pembelajaran dan media sebagai prinsip desain pesan pembelajaran. Penelitan pengembangan produk yang dilakukan ini diarahkan untuk menghasilkan 
suatu produk berupa media pembelajaran interaktif pada pembelajaran Biologi untuk siswa MAN Model Idi Rayeuk kelas X yang digunakan untuk meningkatkan proses pembelajaran maupun kompetensi siswa. Karena itu dalam prosesnya penelitian ini dilakukan dengan diawali studi pendahuluan, kemudian mendesain media pembelajaran, melakukan validasi produk dan melakukan revisi dan penyempurnaan berdasarkan analisis data validasi dari ahli materi, ahli desain pembelajaran dan ahli rekayasa perangkat lunak yang dilanjutkan dengan uji coba perorangan, uji coba kelompok kecil, dan uji coba lapangan sehingga dihasilkan media pembelajaran yang layak digunakan sesuai dengan karakteristik bidang studi dan siswa sebagai pengguna.

Aspek yang direvisi dan disempurnakan berdasarkan analisis data dan uji coba serta masukan dari ahli materi, ahli desain pembelajaran, ahli rekayasan perangkat lunak dan siswa selaku pengguna media pembelajaran interaktif ini, bertujuan untuk menggali beberapa aspek yang lazim dalam proses pengembangan suatu produk. Variabel-variabel media pembelajaran memiliki nilai rata-rata sangat baik. Adapun variabel media pembelajaran yang dinilai meliputi kelayakan isi, penyajian, kebahasaan, pemprograman, dan kegrafikan.

Manfaat yang diperoleh dari penggunaan media pembelajaran interaktif adalah konsep yang disajikan mudah dipelajari, dipahami dan sistematis. Media pembelajaran interaktif memberi kesempatan pada siswa untuk belajar sesuai dengan kecepatan masingmasing, belajar lebih cepat, mandiri dan tidak menimbulkan kebosanan karena dilengkapi dengan gambar-gambar dan animasi serta soal latihan yang bervariasi. Adanya pengulangan yang harus dilakukan saat jawaban salah menjadikan siswa lebih memahami materi. Media pembelajaran interaktif ini juga dapat digunakan sebagai alternatif media pembelajaran secara klasikal maupun individual.

Hasil pengolahan data penelitian yang telah dilakukan, terdapat perbedaan hasil belajar Biologi antara siswa yang dibelajarkan dengan menggunakan media pembelajaran interaktif dan siswa yang dibelajarkan dengan menggunakan buku teks yaitu rata-rata hasil belajar Biologi siswa yang dibelajarkan dengan menggunakan media pembelajaran interaktif lebih tinggi dibandingkan dengan siswa yang dibelajarkan dengan menggunakan buku teks. Hal ini dapat dilihat dari hasil nilai rata-rata Biologi siswa yang diajar dengan media pembelajaran interaktif yaitu sebesar $82,6 \%$, sedangkan hasil nilai rata-rata Biologi siswa yang yang diajar dengan buku teks sebesar $75,2 \%$. Dari data ini membuktikan bahwa penggunaan media pembelajaran interaktif lebih baik dalam meningkatkan pengetahuan siswa dalam pembelajaran Biologi daripada penggunaan buku teks.

Penggunaan media pembelajaran interaktif dalam pembelajaran Biologi memungkinkan siswa untuk berinteraksi langsung dan melakukan kontrol langsung pada sumber informasi, sehingga siswa dapat mengendalikan dan memperoleh apa yang menjadi kebutuhannya, misalnya dapat melihat secara jelas antara perbedaan paku dengan lumut yang ada disediakan dalam media pembelajaran interaktif. Siswa juga dapat mengerjakan soal-soal latihan yang telah dilengkapi skor nilai persentasenya.

Pembelajaran dengan media interaktif juga memungkinkan guru bebas melakukan interaksi dengan siswa sehingga pembelajaran tersebut bersifat interaktif yang membuat pembelajaran terfokus pada informasi yang sedang dipelajari. Hal ini berbeda dengan pembelajaran menggunakan buku teks, siswa tidak berinteraksi langsung pada sumber informasi dan pembelajaran didominasi oleh guru yang menyajikan informasi secara linier atau satu arah. Hal ini terjadi karena pada media pembelajaran buku teks siswa mendapatkan sumber informasi hanya dari guru dan materimateri yang ada dalam buku tanpa bisa memperoleh skor nilai secara langsung dari soal-soal latihan yang dikerjakan. Pembelajaran dengan menggunakan buku teks menempatkan guru sebagai pelaku yang aktif, sementara siswa relatif pasif hanya menerima dan mengikuti apa yang disampaikan guru. Guru menyampaikan materi secara terstruktur dengan harapan materi pelajaran yang disampaikan dapat dikuasai dengan baik dengan terfokus kepada kemampuan akademik.

Walaupun dalam penelitian diperoleh data bahwa hasil belajar Biologi siswa lebih tinggi jika dibelajarkan dengan media pembelajaran interaktif daripada hasil pembelajaran Biologi siswa yang dibelajarkan dengan menggunakan buku teks, namun dalam pelaksanaannya kedua media pembelajaran ini telah mampu meningkatkan pemahaman dan 
hasil belajar Biologi siswa. Keefektifan penggunaan media pembelajaran interaktif adalah sebesar $82,6 \%$ dan buku teks sebesar $75,2 \%$.

Keterbatasan dalam penelitian pengembangan media pembelajaran interaktif dan uji keefektifan produk ini antara lain: (1) Uji coba produk media pembelajaran interaktif hanya dilakukan pada uji coba terbatas dengan sampel 40 siswa kelas X MAN Model Idi Rayeuk T.P 2013/2014. Uji coba luas tidak dilakukan sehingga kemungkinan faktor bisa masih mempengaruhi hasil penelitian. Oleh karena itu sampel pada penelitian harus representatif agar hasil penelitian dapat digeneralisasikan; (2) Kesiapan siswa dan guru untuk terlibat dalam suatu media pembelajaran yang berbeda dengan pembelajaran yang biasa mereka gunakan. Guru terbiasa memberikan materi pelajaran dengan menggunakan buku teks lalu memberi tugas secara terstruktur, kemudian dilakukan evaluasi untuk menentukan penilaian terhadap hasil belajar siswa. Ketidaksiapan guru dalam penggunaan media pembelajaran interaktif dapat diatasi dengan pelatihan untuk meningkatkan kompetensi secara profesioanl. Sedangkan ketidaksiapan siswa dapat diatasi dengan memberi CD pembelajaran interaktif agar dapat digunakan sebagai alat untuk dapat belajar mandiri sehingga dapat meningkatkan kompetensi siswa dan hasil belajar siswa; (3) Siswa yang menjadi subjek penelitian tidak dapat terkontrol secara ketat di luar sekolah, sehingga kemungkinan adanya waktu belajar dan pengalaman belajar yang berbeda dari masing-masing subjek di luar perlakuan yang diberikan pada saat proses pembelajaran di sekolah, dan hal ini tentu dapat mempengaruhi kemampuan siswa. Untuk mengatasi keterbatasan ini kiranya perlu diperhatikan jumlah sampel dimana semakin banyak jumlah sampel tentu hasil penelitian yang dilakukan jauh lebih baik.

\section{PENUTUP}

Berdasarkan rumusan, tujuan, hasil dan pembahasan penelitian pengembangan media pembelajaran interaktif yang dikemukakan sebelumnya maka dapat disimpulkan sebagai berikut:

1. Hasil validasi dari ahli materi terhadap media pembelajaran interaktif pada pembelajaran Biologi yang telah dikembangkan menunjukkan bahwa; (1) kualitas materi pembelajaran dinilai sangat baik, (2) kualitas strategi pembelajaran dinilai sangat baik, (3) kualitas sistem penyampaian pembelajaran dinilai sangat baik. Dengan demikian media pembelajaran interaktif pembelajaran yang dikembangkan dengan menggunakan program Microsoft Powerpoint secara keseluruhan termasuk dalam kategori "Sangat Baik".

2. Hasil validasi dari ahli desain pembelajaran terhadap media pembelajaran interaktif pada pembelajaran yang dikembangkan dengan menggunakan program Microsoft Powerpoint menunjukkan bahwa; (1) Aspek kelayakan isi pembelajaran dinilai sangat baik, (2) Aspek penyajian isi dinilai sangat baik, (3) Aspek kebahasaan dinilai baik, (4) Aspek kegrafikan presentasi dinilai baik. Berdasarkan hasil validasi tersebut disimpulkan bahwa media pembelajaran interaktif pada pembelajaran Biologi yang dikembangkan termasuk dalam kriteria sangat baik sehingga dapat diterima dan layak digunakan dalam proses pembelajaran.

3. Hasil validasi dari ahli rekayasa perangkat lunak terhadap media pembelajaran interaktif pada pembelajaran Biologi yang dikembangkan dengan program Microsoft Powerpoint dinyatakan bahwa; (1) kualitas teknis/tampilan dinilai sangat baik, (2) pemprograman dinilai sangat baik, Dengan demikian media pembelajaran interaktif yang dikembangkan secara keseluruhan termasuk dalam kriteria sangat baik.

4. Menurut tanggapan siswa MAN Model Idi Rayeuk pada uji coba perorangan dinyatakan bahwa media pembelajaran interaktif yang dikembangkan dengan program Microsoft Powerpoint termasuk kategori sangat baik.

5. Menurut tanggapan siswa MAN Model Idi Rayeuk pada uji coba kelompok kecil dinyatakan bahwa media pembelajaran interaktif yang dikembangkan dengan program Microsoft Powerpoint termasuk kategori sangat baik

6. Menurut tanggapan siswa MAN Model Idi Rayeuk pada uji coba lapangan dinyatakan bahwa media pembelajaran interaktif yang dikembangkan dengan program Microsoft Powerpoint termasuk kategori sangat baik.

7. Media pembelajaran yang dikembangkan peneliti layak untuk digunakan sebagai media pembelajaran Biologi untuk MAN Model Idi Rayeuk Kelas X, karena memiliki nilai rata-rata yang lebih tinggi dari nilai median skala Likert. 
8. Terhadap penggunaan media pembelajaran interaktif pada tes hasil belajar siswa menunjukkan bahwa hasil belajar siswa yang dibelajarkan dengan menggunakan media pembelajaran interaktif (kelas eksperimen) lebih tinggi dari hasil belajar siswa yang dibelajarkan dengan menggunakan buku teks (kelas kontrol). Dengan demikian disimpulkan bahwa terdapat perbedaan yang signifikan antara hasil belajar siswa yang dibelajarkan dengan menggunakan media pembelajaran intetraktif dengan hasil belajar siswa yang dibelajarkan dengan menggunakan buku teks, dimana diperoleh thitung sebesar 54,25 sedangkan $t_{\text {tabel }}$ pada $\alpha=0,05$ dengan derajat kebebasan 94 adalah: 1,95 sehingga thitung $(4,25)$ lebih besar dari $t_{\text {tabel }}(1,67)$.

9. Media pembelajaran interaktif memiliki keefektifan sebesar $82,55 \%$ lebih tinggi dari keefektifan menggunakan buku teks sebesar $71,84 \%$.

Berdasarkan hasil temuan yang telah diuraikan pada Simpulan serta implikasi hasil penelitian, berikut ini diajukan beberapa saran yaitu: (1) Pembelajaran selama ini masih menggunakan buku teks maka disarankan kepada guru agar menggunakan media pembelajaran interaktif sehingga mampu memberikan umpan balik yang baik kepada siswa; (2) Selain itu disarankan kepada guru agar memberi motivasi kepada siswa untuk belajar mandiri dengan menggunakan media pembelajaran interaktif, karena siswa akan mendapatkan informasi yang mereka inginkan melalui media pembelajaran interaktif ini dan mereka juga tidak perlu tergantung pada kehadiran guru dalam upaya meningkatkan hasil belajarnya.

\section{DAFTAR PUSTAKA}

Anderson, O.W. dan Krathwohl, D.R. 2001. Taxonomy for Learning, Teaching, and Assessing. New York: Addison Wesley Longman, Inc.

Arends, R. 2008. Learning to Teach. Yogjakarta: Pustaka Pelajar.

Ary, D. Jacobs, L.C Razavieh, A. (1982). Pengantar Penelitian Dalam Pendidikan. (Penerjemah Furcham, A). Surabaya: Usaha Nasional.

Bobbi DePorter, Dkk .2007. Quantum Teaching. Bandung : Penerbit Kaifa.

Djamarah, Saiful.2006.Strategi Belajar Mengajar.Jakarta : Rineka Cipta.
Dahar, Ratna Wilis. 1989. Teori-Teori Belajar. Bandung : PT. Gelora Aksara Pratama.

Dick, W. \& Carey, L. 2005. The Systematic Design of Instruction. Glenview, Illinois: Scoot, Foresman and Company.

Frick, Heinz. 2003. Ilmu Konstruksi Stuktur Bangunan. Yogyakarta : Kanisius

Gagne, R. M. 1977. The Condition of Learning. New York: Halt Rinerhart and Winston.

Gerlach and Elly. 1980. Teaching and Media Asystematic Approach. Englewood Cliffs, N.J.

Gunawan A.W. 2007. Born to be A Genius. Jakarta: Gramedia Pustaka.

Hernowo. 2004. Vitamin $T$ : Bagaimana Mengubah Diri Lewat Membaca dan Menulis. Bandung : Mizan Learning Center.

. 2005. Quantum Reading: Cara Cepat nan Bermanfaat Untuk Merangsang Munculnya Potensi Membaca. Bandung : Mizan Learning Center.

Juhana 0, Suratman M. 2000. "Menggambar Teknik Mesin". Bandung: Pustaka Grafika.

Lassei. 1986. The Great of Brain. New York: Macmillan Company.

Lazzader. 2003. Menggambar Teknik Dasar. Jakarta: PT. Gramedia

Munandar, Utami. 1998. Memupuk Bakat dan Kreativitas Siswa Sekolah Menengah. Jakarta: PT. Gramedia

Nasoetion, N. dan Suryanto. A. Tes, Pengukuran, dan Penilaian. Jakarta: Pusat Penerbitan UT. 2002.

Nasution, S. 2005. Berbagai Pendekatan Dalam Proses Belajar dan Mengajar. Jakarta : Bumi Aksara.

Nurhadi. 2003. Contextual Teaching and Learning. Jakarta: Depdikbud Dirjen Dikti.

Prawiradilaga, D.S. 2007. Prinsip Desain Pembelajaran. Jakarta : Kencana

Rakhmat, Jalaluddin. 2006. Belajar Cerdas. Bandung : Mizan Learning Center.

Sanjaya, Wina. 2009. Strategi Pembelajaran Berorientasi Standar Proses Pendidikan. Jakarta : Kencana Prenada Media Group

Shindunata. 2000. Mengagas Paradigma Baru Pendidikan. Jakarta : Kanisius.

Soemanty, Wasty, 1984, Psikologi Pendidikan. Jakarta: Bina Aksara

Seels, B.B \& Richey. 1994. Instructional Technology: The Defenition and Domain of Field. Washington, DC : AECT. 
Suryosubroto, B. 2009. Proses Belajar Mengajar Disekolah. Jakarta : Rineka Cipta.

Snelbecker, G. 1974. Learning Theory, Instructiona Theory, and Psychoeducational Design. New York: McGraw-Hill Book Company.

Tan, O.S. 2004. Students' experiences in problem-based learning: Three Blind Innovations in Education and Teaching International. Singapore: Thomson Learning.

Uno, H. 2008. Perencanaan Pembelajaran. Jakarta: Bumi Aksara.

Winkel, W. S. 2007. Psikologi Pengajaran. Yogyakarta: Media Abadi.

Wena,M. 2009. Strategi Pembelajaran Inovatif Kontemporer. Jakarta: Bumi Aksara.

Windura, Sutanto. 2008. Mind Map Langkah Demi Langkah. Jakarta : Elex Media Komputindo 